\title{
Stress and the control of $\mathrm{LH}$ secretion in the ewe
}

\author{
R. F. Smith ${ }^{1}$, S. P. S. Ghuman ${ }^{1}$, N. P. Evans², F. J. Karsch ${ }^{3}$ \\ and $\mathrm{H}$. Dobson ${ }^{1}$ \\ ${ }^{7}$ Department of Veterinary Clinical Science, University of Liverpool, Leahurst, Neston, Cheshire \\ CH64 TTE, UK; ${ }^{2}$ Department of Veterinary Preclinical Studies, University of Glasgow, Bearsden \\ Road, Glasgow G61 1QH, UK; and ${ }^{3}$ Reproductive Sciences Program, Department of Physiology, \\ University of Michigan, Ann Arbor, MI 48109, USA
}

\begin{abstract}
Stress influences the activity of the reproductive system at several sites. One of the most significant effects is at level of the GnRH secretory system to reduce GnRH pulsatility and thus LH pulsatility. This in turn reduces the oestradiol signal that stimulates the $\mathrm{GnRH}-\mathrm{LH}$ surge in the follicular phase. Three sequential phases have been identified in the induction of the $\mathrm{GnRH}-\mathrm{LH}$ surge by oestradiol: (i) activation, (ii) transmission and (iii) surge secretion. There is evidence that administration of endotoxin prevents activation but not transmission, hypoglycaemia blocks both activation and transmission, whereas truck transport is effective during the late, but not early, transmission phase. Opioids mediate the suppressive effects of hypoglycaemia on both LH pulsatility and the delayed onset of the LH surge in ewes. The exact neurocircuitry used in sheep is yet to be identified but many of the connections that are proposed as important in rats are present in sheep. Corticotrophin-releasing hormone $(\mathrm{CRH})$ neurones in the paraventricular nucleus that project axons to the median eminence probably do not directly inhibit $\mathrm{GnRH}$, but either afferent or parallel central pathways are involved. New members of the CRH peptide and receptor families have been identified, but roles in the control of reproduction have yet to be determined.
\end{abstract}

\section{Introduction}

Successful passage of genes to the next generation is a key biological drive in all species and the need to reproduce has not diminished with domestication of ruminants. Attainment of optimum fertility under agricultural systems is the key to economic farm production of milk, meat and wool. Conception requires a robust display of oestrous behaviour and ovulation of a mature oocyte coordinated with a supply of competent spermatozoa enabling fertilization in a favourable environment. After luteolysis, the exact timing of events in the follicular phase is dependent on the interplay between GnRH (and thus LH) pulse frequency and amplitude and oestradiol production. This culminates in GnRH and LH surges, stimulation of oestrus behaviour and ovulation (McNeilly et al., 1991). 
Table 1. Summary of factors influencing GnRH secretion and the possible signalling pathways to the hypothalamus in sheep

\begin{tabular}{ll}
\hline Factor & Major signal to the hypothalamus \\
\hline Stored energy availability & Leptin and insulin \\
Season (projected nutrient supply) & Melatonin \\
State of follicular development & Oestradiol \\
State of possible pregnancy & Progesterone \\
Untavourable environment (stress) & CRH, opioids, glucocorticoids \\
\hline
\end{tabular}

$\mathrm{CRH}$ : corticotrophin-releasing hormone.

There have been many definitions of stress but a simple and useful definition is 'any stimulus, real or perceived, which may threaten homeostasis'. Thus, stressors produce signals of (potentially) adverse environmental conditions. The formation of a conceptus marks a commitment to future increased metabolic load. This additional cost may place the mother and the conceptus in jeopardy if environmental conditions become unfavourable. On this basis, animals are subject to evolutionary pressure to ensure that environmental conditions are optimal at the time of maximum metabolic demand (late gestation and lactation). This necessitates the restriction of breeding activity to specific times to ensure future resource availability. In addition, as general environmental conditions cannot be predicted far in advance, if an environment is perceived as at all stressful it would be unsafe to commit to any additional future metabolic load. Thus, suppression of reproduction by stressful stimuli has evolutionary advantages.

Stressors may alter endocrine systems in three distinct ways: (i) as a stimulus-specific response, for example hormones involved in body fluid regulation may be released in response to haemorrhage; (ii) as a generalized response to stimuli (for example, sympathetic nervous system (SNS) activity, hypothalamic-pituitary-adrenal axis (HPA)) or (iii) a hormone may have a key role in normal body function (for example reproduction) and stress may deleteriously alter the hormone signal thus preventing normal function (Smith and Dobson, 2002).

The hypothalamus is the predominant centre for the integration of the many factors that influence control of key body functions, including reproduction. A wide range of physiological signals, acting over diverse time frames, impinge on the hypothalamus to influence the likelihood of a successful reproductive outcome (Table 1). The hypothalamus is the major site of control, and GnRH neurones are pivotal in linking hypothalamic control centres via the hypophysial portal blood system to the rest of the body. However, the pituitary gland and ovaries may also be directly affected.

In experimental studies, both inhibitory and stimulatory effects of a diverse range of stressors modulate various aspects of reproduction. However, even ordinary events in the normal production cycle of domesticated ruminants are stressful and deleterious to reproduction (Dobson and Smith, 2000). As an example of the possible magnitude of stress on fertility, cattle subjected to fixed time Al and subsequent daily blood sampling in an unfamiliar environment had a pregnancy rate of $28 \%$ and a large proportion of non-pregnant animals had prolonged follicular phases and cystic ovaries. However, pregnancy rates improved markedly $(86 \%)$ in animals habituated to the management regimen. This finding indicates that stressinduced delay or failure of ovulation was the prime lesion causing subfertility (Mann, 2001). This review focuses on the mechanisms by which stressors may influence normal hormonal changes in the follicular phase of female ruminants, principally the ewe, to account for such observations. 


\section{Impact of study design}

Most studies on the effect of stress on reproduction have used animals in the follicular phase, as this is the time of the co-ordinated events that culminate in ovulation and conception. The effect of stress in the luteal phase on reproductive parameters has not been studied extensively. In ewes, cortisol infusion has a greater suppressive effect on subsequent ovulation if it is administered in the follicular rather than the luteal phase (Macfarlane et al., 2000). Moreover, recent studies in primates indicate that stress during the follicular phase can also have detrimental effects on subsequent corpus luteum function (Xiao et al., 2002). This review will concentrate on the greater body of knowledge generated by studies carried out in the follicular phase.

Interpretation of experimental results is dependent on actual study designs. This is very marked for experiments studying the effects of stress as even experimental procedures may interfere and be perceived as stressful. Furthermore, appreciation of stressor-induced endocrine changes also requires an understanding of all factors that impinge on both the HPA and hypothalamic-pituitary-ovarian axis (HPO).

Experimental protocols involving exposure to psychological and environmental stimuli (isolation/restraint, road transport in a truck) or response to administration of compounds that challenge homeostasis (insulin, endotoxin) have been used to investigate the mechanisms involved in stress-induced suppression of GnRH-LH. All of these stimuli cause an initial robust increase in portal blood concentrations of both corticotrophin-releasing hormone $(\mathrm{CRH})$ and arginine vasopressin (AVP), leading to adrenocorticotrophic hormone (ACTH) secretion from the pituitary gland. ACTH ultimately stimulates cortisol release from the adrenal glands (Engler et al., 1988; Caraty et al., 1990; Karsch et al., 2002; Smith and Dobson, 2002). Subsequently, concentrations of all hormones within the HPA may decrease due to the combined effect of habituation to the stimulus and cortisol negative feedback (Smith and Dobson, 2002). Individual components of the HPA cascade have also been administered to animals to determine which compounds could mediate the effect of stress on reproduction. However, such pharmacological evidence should be interpreted with care as responses to injections or infusions are not reduced over time by habituation or cortisol negative feedback, as are endogenous stress responses. There is also growing evidence that the magnitude of HPA response is modulated by the sex hormone milieu (Tilbrook et al., 2000).

Several experimental approaches have been used to clarify which parts of the normal reproductive endocrine cascade are most sensitive to the effects of stress. The use of ovaryintact animals permits the impact on LH pulse frequency to be monitored while allowing $\mathrm{LH}$ to alter oestradiol production endogenously. Such studies allow subsequent changes in oestradiol to exert feedback control on LH pulse frequency and timing of the periovulatory LH surge. Alternatively, ovariectomized (OVX) animals that have had steroid replacement have been used to study the effect of stressors on $\mathrm{LH}$ release without the overlying complication of varying the oestradiol feedback signal. However, steroid replacement regimens do not mimic the natural situation perfectly. Variations between individuals in absolute progesterone concentration and the rate of decrease in plasma progesterone after luteolysis also influence $\mathrm{LH}$ release. Therefore, many studies have controlled these variables by imposing an artificial luteal phase with a fixed dose of exogenous (intravaginal) progesterone combined with the removal of any endogenous corpora lutea using prostaglandin $\mathrm{F}_{2 \alpha}$ (Van Cleeff et al., 1998).

As $97 \%$ of $\mathrm{LH}$ pulses in peripheral blood are coincident with a $\mathrm{GnRH}$ pulse in portal blood, $\mathrm{LH}$ can be measured to reflect GnRH pulse frequency and the time of GnRH surge onset (Moenter et al., 1990). The amplitude of $\mathrm{LH}$ pulses reflects a combination of $\mathrm{GnRH}$ pulse amplitude and pituitary gland sensitivity to GnRH. Pituitary gland sensitivity to GnRH 

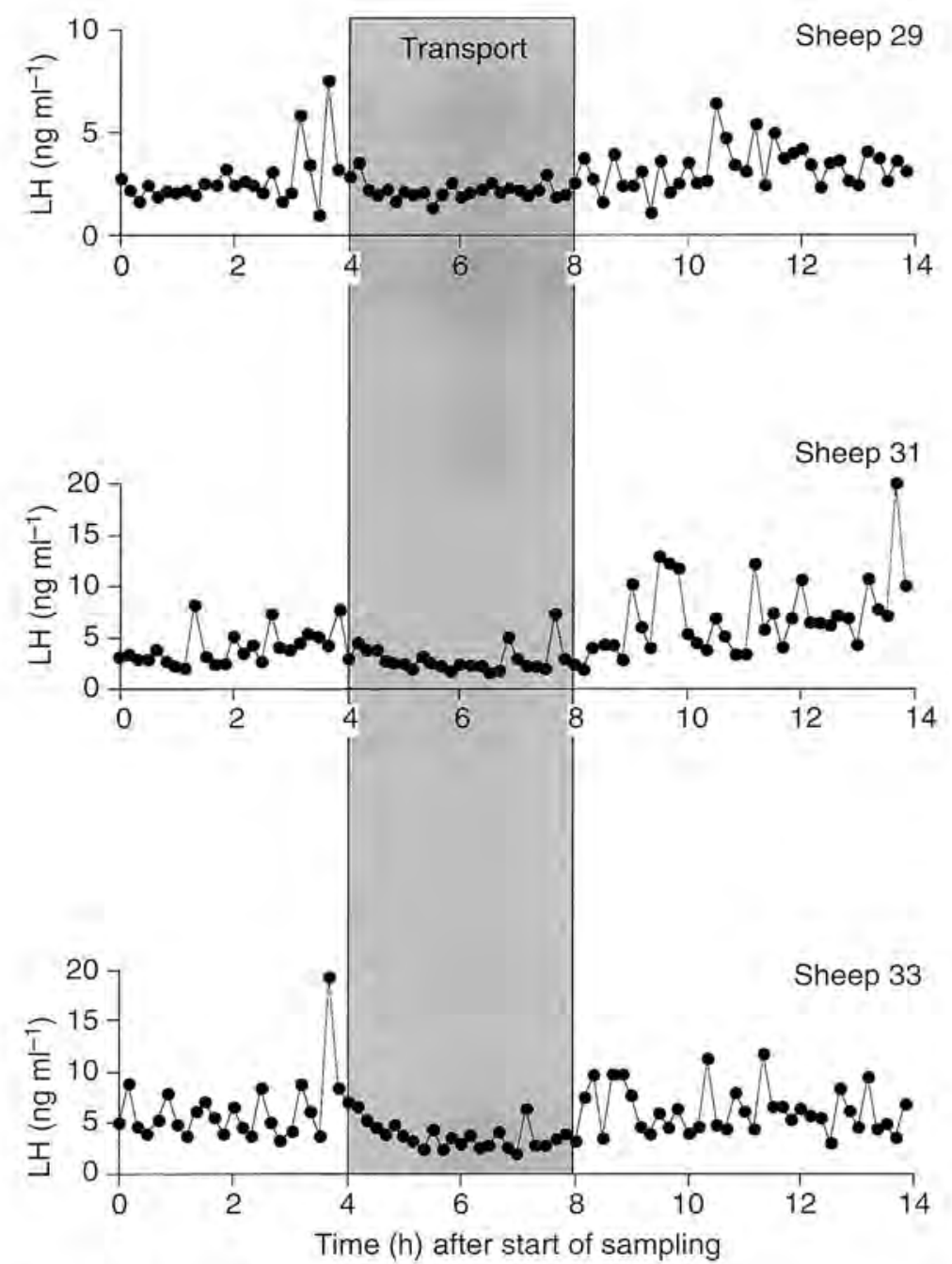

Fig. 1. Profiles of $\mathrm{LH}$ in the peripheral plasma of three representative ovariectomized ewes transported in a truck on metalled roads for $4 \mathrm{~h}$ (shaded area) in the mid-breeding season without prior steroid treatment. Note different scale on upper profile.

can be studied by challenges with exogenous GnRH but the effect on GnRH self-priming (the ability of one GnRH pulse to increase or maintain the response to the next pulse) requires injection of at least two doses of GnRH (Phogat et al., 1999a). When there is a marked stressor effect at the pituitary gland, LH pulse amplitude may be suppressed to such an extent that measurable LH pulse frequency may be lower than the actual GnRH pulse frequency (Karsch et al., 2002). Thus, the direct measurement of GnRH in hypophysial portal blood remains the gold standard for monitoring the impact of stress on GnRH release. However, $\mathrm{LH}$ concentrations may be influenced by loss of $\mathrm{GnRH}$ signal during the sampling process itself. This may be the underlying reason why animals prepared for portal blood collection show a longer latency from progesterone removal to $\mathrm{LH}$ surge onset than control animals (Dobson et al., 1999). 


\section{Effect of stress on GnRH-LH pulsatility}

\section{Frequency}

GnRH-LH pulse frequency is totally suppressed in some individuals by exposure to stress (Figs 1-3). However, differences between studies in parameters such as season of year and sex hormone treatments affect responses and make direct comparisons difficult (Table 2). The severity of suppression of $\mathrm{GnRH}-\mathrm{LH}$ pulsatility appears to parallel the degree of HPA stimulation both within and between studies. The rank order of stressor severity in commonly applied models increases through isolation, transport, insulin-hypoglycaemia to the most severe, endotoxin administration (Dobson and Smith, 1998; Tilbrook et al., 2000; Karsch et al., 2002). Daily repetition of stress leads to habituation of the inhibitory effect on LH pulse frequency and amplitude in a similar manner to that during habituation of the HPA response (Rasmussen and Malven, 1983). However, prolongation of stress does not always lead to continued suppression of $\mathrm{LH}$ pulse frequency. For example, $\mathrm{LH}$ pulse frequency is only significantly reduced for the first $4 \mathrm{~h}$ of an $8 \mathrm{~h}$ transport period (Phogat et al., 1999a), and during prolonged hypoglycaemia LH pulsatility resumes, whereas blood glucose concentrations are still suppressed (H. Dobson and R. F. Smith, unpublished).

\section{Amplitude}

LH pulse amplitude is decreased by almost all the stressors listed above and a reduction in $\mathrm{GnRH}$ pulse amplitude by endotoxin has been observed (Karsch et al., 2002). However, gonadotroph responsiveness to $\mathrm{GnRH}$ can also be reduced by the severe stress of endotoxin (Karsch et al., 2002); and although moderate transport stress does not suppress the response to one injection of exogenous $\mathrm{GnRH}$, it does reduce $\mathrm{GnRH}$ self-priming which results in lower $\mathrm{LH}$ responses to subsequent $\mathrm{GnRH}$ pulses (Phogat et al., 1999a).

\section{Consequences at the ovary}

In ovary-intact animals, stress-induced lowered LH pulsatility slows follicular growth and reduces ovarian oestradiol production. This finding has been confirmed by administering exogenous $\mathrm{LH}$ pulses to mimic those observed during transport in ewes bearing ovarian autotransplants and treated with $\mathrm{GnRH}$ antagonists to suppress endogenous $\mathrm{LH}$ production (Dobson and Smith, 1998). A reduction in oestradiol production in ovary-intact animals may be the cause of the increased delay in the onset of the LH surge observed in these animals compared with OVX and oestradiol-treated animals, when all are transported just before the time of the expected LH surge (Dobson and Smith, 1998).

\section{Effects of stress on the GnRH-LH surge}

\section{Timing of onset}

Three phases in the induction of an oestradiol-induced GnRH-LH surge have been identified: (i) activation, (ii) transmission and (iii) surge secretion (Fig. 4) (Evans et al., 1997). Transport blocks or delays the LH surge of intact ewes when it is timed to coincide with the late transmission or early surge secretion phases (Dobson and Smith, 2000). However, hypoglycaemia (10-12 h) induced during any of the phases delays the surge in oestradiol-treated OVX ewes (Medina et al., 1998). Moreover, endotoxin administration blocks activation and the early transmission phase but was without affect when applied during the late transmission 

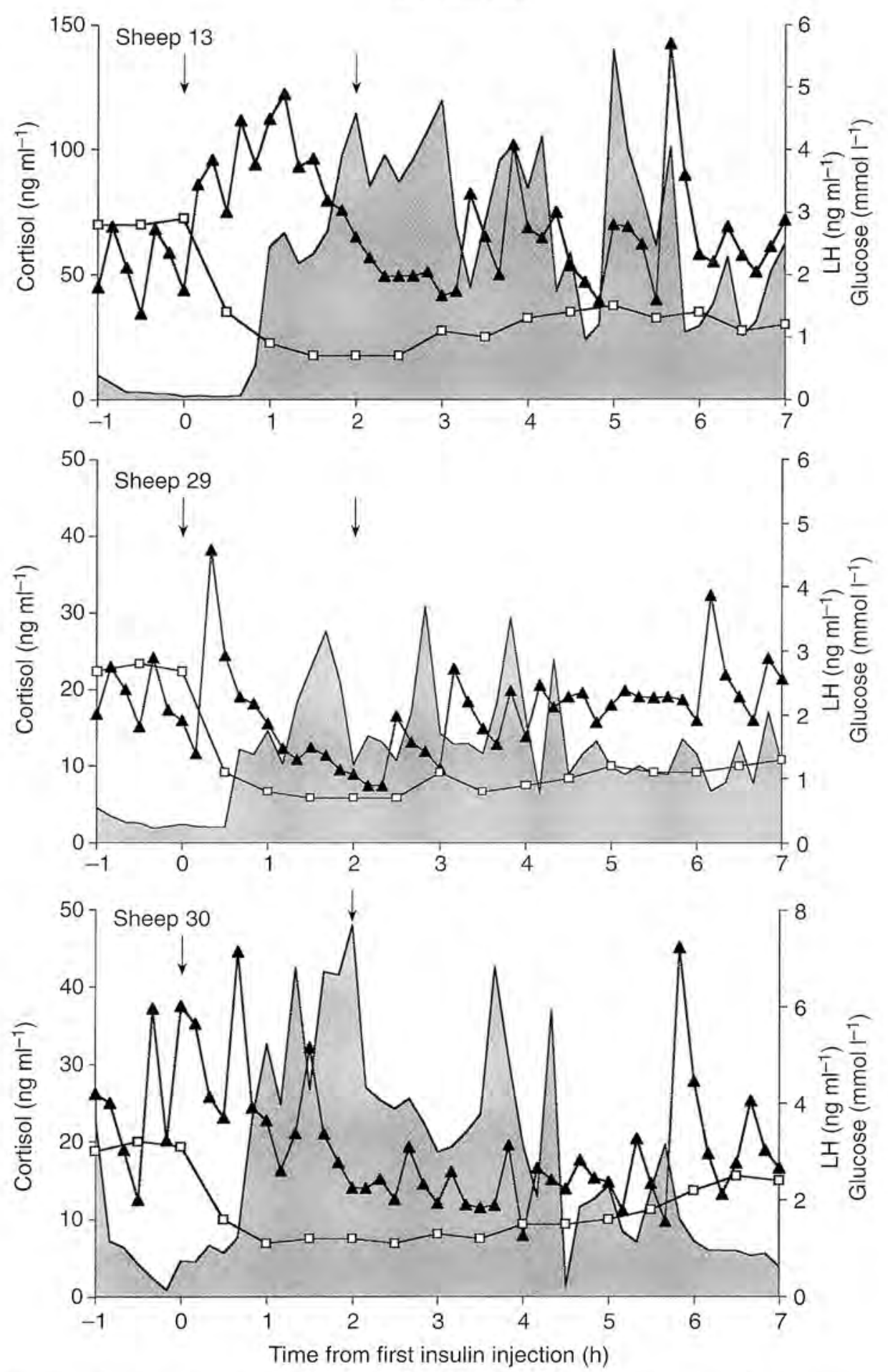

Fig. 2. Profiles of cortisol (shaded area), $\mathrm{LH}(\mathbf{\Delta})$ and glucose $(\square)$ in peripheral plasma of three representative ovariectomized ewes administered $1 \mathrm{iu}$ insulin $\mathrm{kg}^{-1}$ at 0 and $2 \mathrm{~h}$ (arrows) in the mid-breeding season without prior steroid treatment. Note different scales on each profile. 

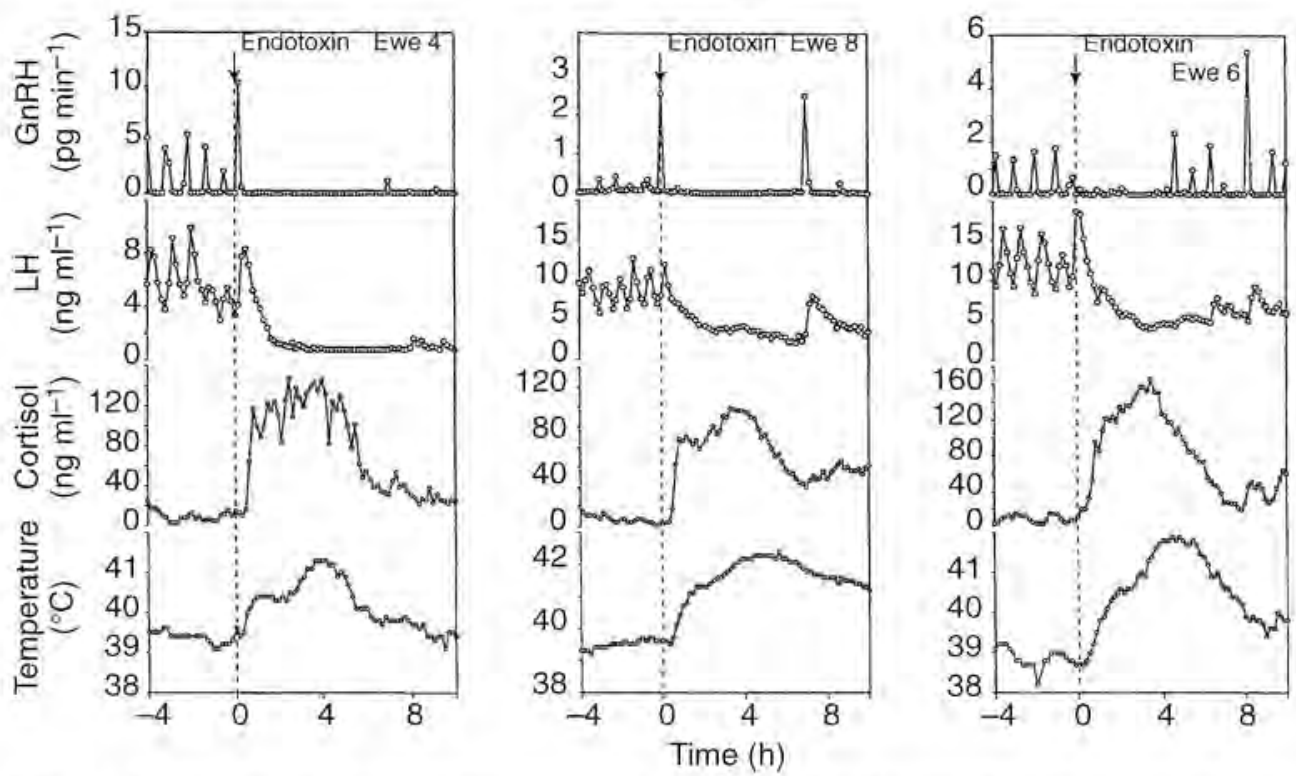

Fig. 3. Profiles of $\mathrm{GnRH}$ in portal plasma, $\mathrm{LH}$ and cortisol in the peripheral plasma and core body temperature of three representative ovariectomized ewes that were not treated with steroid but received endotoxin $\left(400 \mathrm{ng} \mathrm{kg}^{-1}\right.$ ) at $0 \mathrm{~h}$ (dashed vertical line). Note different scales on each profile, (Reproduced from Battaglia DF, Bowen JM, Krasa HB, Thrun LA, Viguie C and Karsch FJ (1997) Endotoxin inhibits the reproductive neuroendocrine axis while stimulating adrenal steroids: a simultaneous view from hypophyseal portal and peripheral blood Endocrinology $1384273-4281$. Copyright owner, The Endocrine Society).

or surge secretion phases (Karsch et al., 2002). Isolation or restraint can also block the surge when applied in the late transmission phase, but effects during other phases have not yet been investigated ( $\mathrm{H}$. Dobson and R. F. Smith, unpublished). Identification of the mechanisms underlying the differential effects of various stressors could give important insights into the locations and neurotransmitters involved in the three phases during normal GnRH-LH surges.

\section{Amplitude and duration}

There are also differential effects of stressors on surge amplitude depending on the phase of the surge mechanism during which the stress is applied (Fig. 4), but there are no stressinduced changes in the duration of the surge. Transport during the late transmission phase suppresses surge amplitude in both ovary intact and OVX oestradiol-treated ewes (Dobson and Smith, 1998). Hypoglycaemia also reduces surge amplitude when applied during the transmission phase in oestradiol-treated OVX ewes. Conversely, hypoglycaemia or endotoxin administration during the activation phase had no effect on the amplitude of the surge. Endotoxin administration during the transmission phase was also without effect on either LH surge parameter (Karsch et al., 2002). The differential effects of different stressors on each phase of the GnRH-LH surge provide an opportunity to identify which neuronal pathways are active in each phase by studying differential neuronal activation during each stress. 


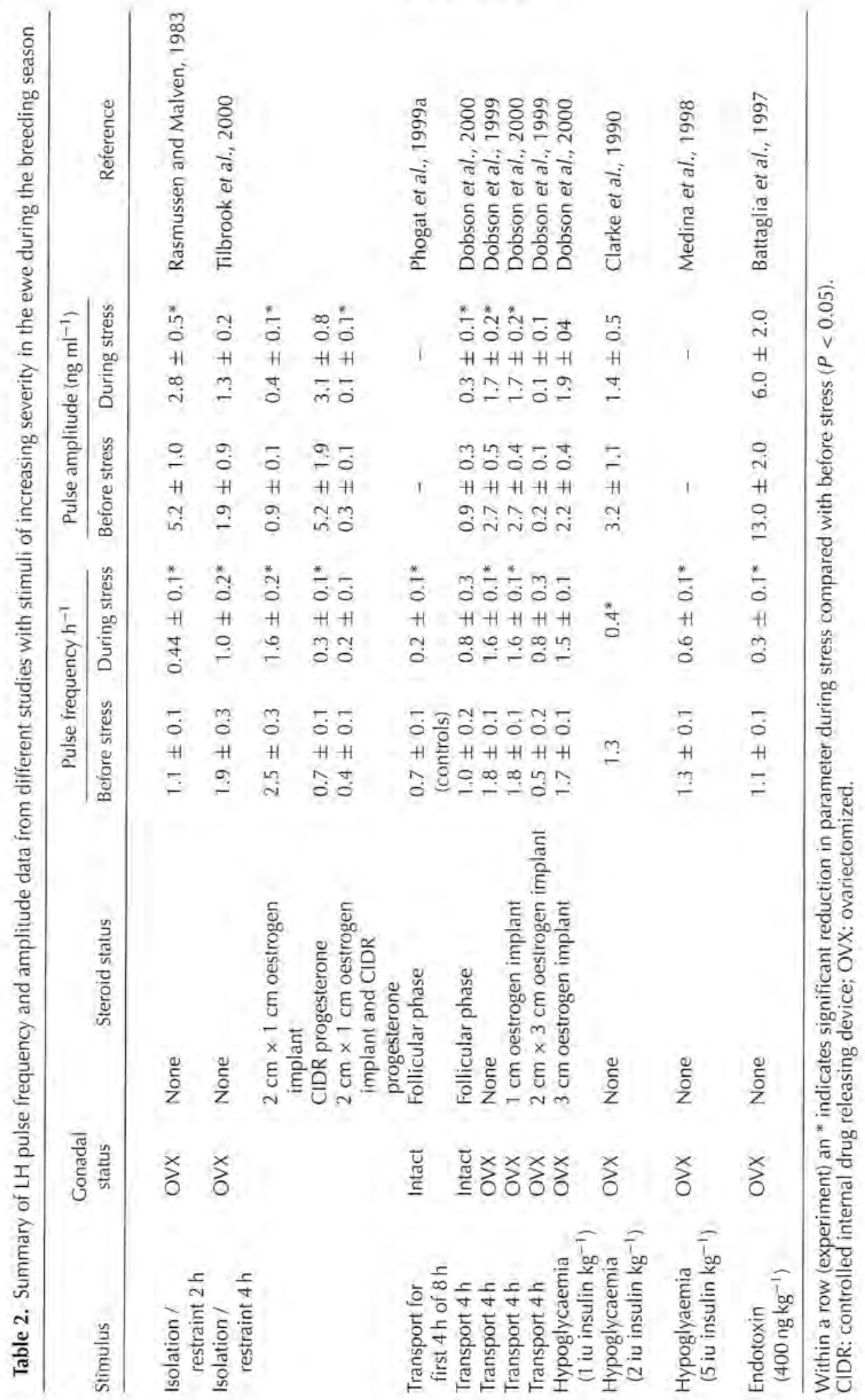




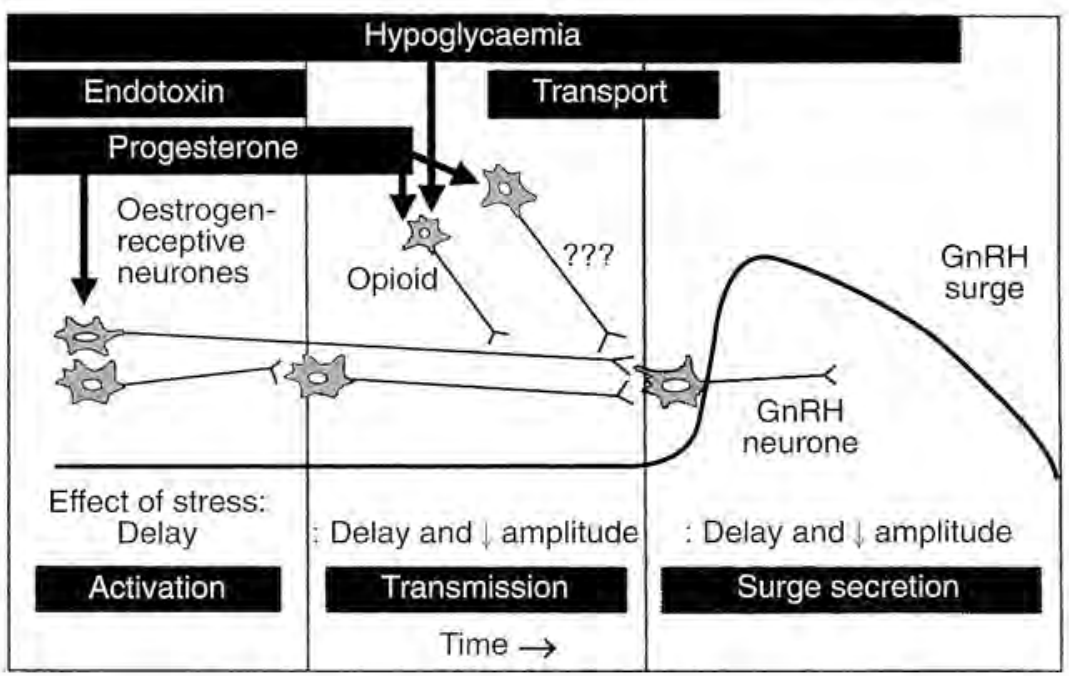

Fig. 4. Representation of the phases during induction of a $\mathrm{GnRH}$ surge when transport, insulin-induced hypoglycaemia, endotoxin or progesterone can delay the surge with possible neurocircuitry also shown. Adapted from Evans et al. (1997). Data from Smart (1994), Medina et al. (1998) and Karsch et al. (2002).

\section{Possible HPA mediators of the effect of stress on reproduction}

In the following summary, data from sheep will be discussed; when not available or contradictory, reference will be made to studies in other species for clarification. An in-depth review of potential intra-hypothalamic pathways mediating the effect of stress on reproduction has been published (Dobson et al., 2003).

\section{Arginine vasopressin}

Arginine vasopressin (AVP) is the most abundant hypothalamic hormone secreted from the paraventricular nucleus (PVN) of the hypothalamus in response to stress and is the main stimulus for ACTH secretion in sheep (Smith and Dobson, 2002). However, intracerebroventricular injection of AVP alone in males or in combination with CRH in OVX females fails to alter LH secretion in sheep, although AVP suppresses LH release in primates (Heisler et al., 1994; Tilbrook et al., 2000). The involvement of AVP receptors in stress-induced inhibition of GnRH-LH has not been studied in ruminants to date. Studies in female primates have been contradictory: hypoglycaemia-induced suppression of $\mathrm{LH}$ release has been both inhibited and permitted by AVP receptor antagonism (Heisler et al., 1994; Chen et al., 1996). The role of AVP is no clearer in rats. High doses of AVP suppress $\mathrm{LH}$, but AVP antagonism does not reverse hypoglycaemia-induced suppression of LH release (Cates et al, 1999). Moreover, pretreatment with AVP-antiserum prolongs the inhibitory effect of $\mathrm{CRH}$ on the $\mathrm{LH}$ surge (Roozendaal et al., 1996). Further studies in ruminants are required but it should be noted that no cells express AVP mRNA in the bed nucleus of the stria terminalis (BNST), the amygdala, or the medulla and brainstem regions (Matthews et al., 1993). It has been suggested that these are key control areas for stress-induced suppression of $\mathrm{LH}$ in rats (Rivier and Rivest, 1991). 


\section{Corticotrophin releasing hormone}

Corticotrophin releasing hormone (CRH) is the predominant corticotrophin-releasing compound in rats and has an important role facilitating AVP action in sheep. In most species, both central and peripheral administration of $\mathrm{CRH}$ suppresses $\mathrm{LH}$ secretion in the majority of studies. Oestrus and ovulation do not occur in intact ewes infused with CRH i.c.v. (Polkowska and Przekop, 1997). Furthermore, GnRH self-priming is reduced by CRH in vitro (Smart, 1994). However, restraint stress can still suppress $\mathrm{LH}$ secretion in $\mathrm{CRH}$-deficient mice (Jeong et al., 1999). The results of the last study either questions the requirement for $\mathrm{CRH}$ or indicates the existence of compensatory mechanisms in neuroendocrine systems.

The situation in sheep is yet more perplexing. In three laboratories, i.c.v. administration of $\mathrm{CRH}$ increased $\mathrm{LH}$ pulse frequency and mean $\mathrm{LH}$ concentration. All of these studies used gonadectomized animals and responses were obtained only in steroid pre-treated animals of either sex (Naylor et al., 1990; Caraty et al., 1997; Tilbrook et al., 2000). Endogenous stimulation of $\mathrm{LH}$ pulsatility also occurred when OVX ewes were transported $38 \mathrm{~h}$ after removal of exogenous oestradiol and progesterone implants during the transition into anoestrus (Fig. 5). There was no difference in the cortisol response to stress between animals. However, an increase in LH pulsatility was observed during stress in ewes that had entered seasonal oestradiol negative feedback and had few or no LH pulses during the control period. The ewes that still had LH pulses were suppressed as usually observed in the breeding season (Dobson et al., 1999), thus steroid negative feedback may be required for CRH stimulation of $\mathrm{LH}$ to occur. It is proposed that either exogenous $\mathrm{CRH}$ or stress-induced endogenous $\mathrm{CRH}$ overcomes the inhibitory effect of steroids on $\mathrm{LH}$ rather than $\mathrm{CRH}$ directly stimulating $\mathrm{LH}$ pulsatility.

$\mathrm{CRH}$ has been proposed as a major intra-hypothalamic mediator of the effects of stress (Rivier and Rivest, 1991), but how does it reach its site(s) of influence? There are insufficient data to propose a model based solely on work in ewes. The following observations can be made based on knowledge of neurocircuitry present in sheep and functional data from rats. Major CRH neurones pass from the PVN to the external layer of the median eminence (ME). These terminals are not closely associated with the GnRH-rich areas indicating that the $\mathrm{ME}$ does not have major importance in $\mathrm{CRH}-\mathrm{GnRH}$ interactions. $\mathrm{CRH}$ fibres also project rostrally from the PVN towards the MPOA, but have not been traced further forward than the anterior commissure (Paull et al., 1982). Secretory activity of most CRH neurones in the PVN is suppressed by basal and stress-induced cortisol concentrations, but activation of these CRH neurones during removal of corticoid suppression does not inhibit GnRH-LH in sheep or primates (Van Vugt et al., 1997; Debus et al., 2002). Moreover, lesions to the PVN do not prevent footshock-induced suppression of L.H in rats (Rivier and Rivest, 1991). These observations indicate that the PVN neurones projecting to the ME are not involved in stress-induced suppression of GnRH-LH.

Important CRH-positive synapses have been identified on GnRH perikarya in the MPOA in rats, but not yet in ewes. CRH is present in the ovine mPOA. Although CRH mRNA has not been identified there, neurones do project to the MPOA from several other brain regions expressing CRH mRNA (Palkovits et al., 1983; Matthews et al,, 1991). For example, the $\mathrm{CRH}$ content of the amygdala increases in response to a barking dog, and fibres from the amygdala innervate the MPOA in ewes, although the identity of these fibres has not yet been determined (Palkovits et al., 1983; Cook, 2001). In addition, CRH cells are present in the hindbrain (locus coeruleus and nucleus of the solitary tract) in ewes and noradrenergic neurones project from these nuclei to the MPOA (Palkovits et al., 1983; Matthews et al., 1991). Lesions of the locus coeruleus in rats suppress GnRH release (Anselmo Franci et al., 1997). 


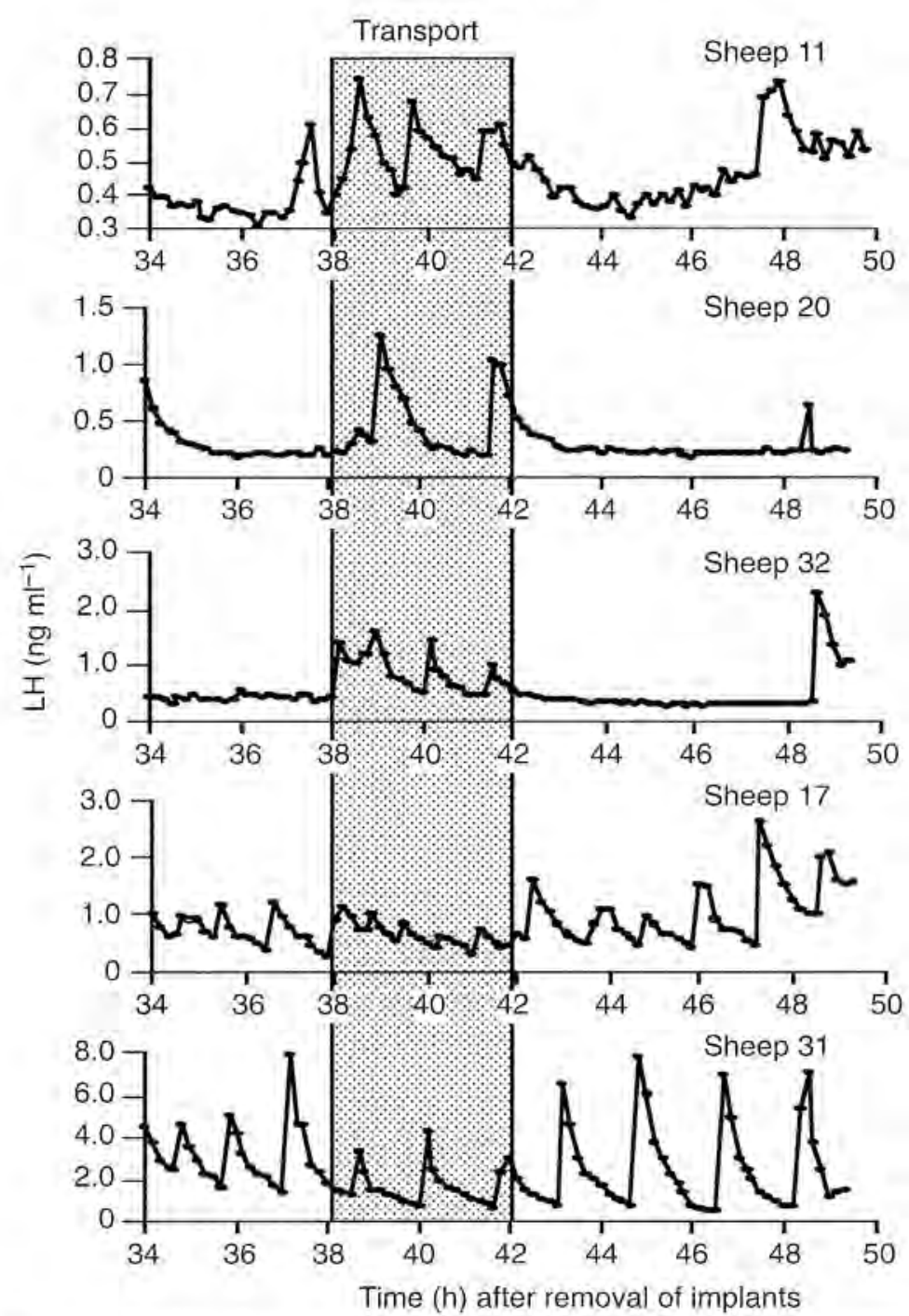

Fig. 5. Profiles of $\mathrm{LH}$ in the peripheral plasma of five representative ovariectomized ewes that were transported after steroid removal during transition into anoestrus (shaded area) for $4 \mathrm{~h}$. Note stimulation of $\mathrm{LH}$ during transport in first three ewes (sheep, 11, 20 and 32) that were suppressed before transport and suppression of pulse amplitude in the last two ewes (sheep 17 and 31) that were actively pulsing before transport. Data obtained from Dobson et al. (1999) with permission.

However, CRH injection into the locus coeruleus increases noradrenaline release and, thus, may stimulate rather than suppress GnRH release (Schulz and Lehnert, 1996). The arcuate nucleus also contains CRH in ewes (Palkovits et al., 1983). Antagonism of CRH within the rat arcuate nucleus-ME results in a decrease in beta-endorphin and an increase in GnRH release (Nikolarakis et al., 1988). Thus, there are several locations at which CRH is present in ewes and could influence $\mathrm{Gn} \mathrm{RH}$ release. 
Other CRH-like peptides and CRH receptors (CRH-R) may also be involved in the control of GnRH. The family includes three ligands: urocortin, urocortin II (stresscopin-related peptide) and urocortin III (stresscopin) and two receptors. CRH has higher affinity for CRH-R1 than CRH-R2. Conversely, urocortin preferentially binds to CRH-R2 > CRH-R1, whereas urocortin II and III act only on CRH-R2. Both CRH-R1 and CRH-R2 are expressed in GnRH cell lines (Tellam et al., 2000). Urocortin has more limited distribution in sheep than in rat brain and is predominantly localized in the Edinger-Westphal nucleus, and several cranial nerve nuclei (Cepoi et al., 1999). Urocortin stimulates LH pulsatility when administered i.c.v. in OVX ewes. However, LH was stimulated only on day 3, and not on day 1 or day 5, of a 5 day experiment using linearly increasing doses of urocortin (Holmberg et al., 2001). The distribution of urocortin II or III in ruminants has not been studied to date. In rats, urocortin III neurones are in the median preoptic nucleus and in the rostral perifornical area lateral to the PVN. Urocortin III fibres innervate the ventromedial nucleus, medial preoptic nucleus, and ventral premammillary nucleus, the lateral septum, the BNST, and the medial nucleus of the amygdala. Most of these areas also express high concentrations of CRH-R2 (Li et al., 2002). The possibility that these new $\mathrm{CRH}$-related peptides and receptors are involved in the control of reproduction warrants further study and may clarify the contradictions between species reported so far for $\mathrm{CRH}$.

\section{Adrenocorticotrophic hormone}

Many studies have used adrenocorticotrophic hormone ( $\mathrm{ACTH}$ ) to stimulate adrenal cortisol (and progesterone) secretion. Most of these studies use high doses of ACTH for several days which circumvents hypothalamic feedback mechanisms and, thus, are not representative of normal HPA function. Treatment of cattle in the follicular phase with ACTH for several days suppresses LH pulse frequency, decreases oestradiol production, increases progesterone and cortisol concentrations and, thus, delays onset of the GnRH-LH surges and behavioural oestrus. A high proportion of animals treated in this way develop follicular cysts (Dobson et al,, 2000). Single injections of ACTH during the transmission phase of the $\mathrm{GnRH}-\mathrm{LH}$ surge induction mechanism delay or prevent the $\mathrm{LH}$ surge. Interestingly, animals that did not have an LH surge tended to have higher plasma progesterone concentrations than those that did have an LH surge (Phogat et al., 1999a). Both in vivo and in vitro studies also indicate that ACTH has a direct action within the pituitary gland to reduce GnRH self-priming (Phogat et al., 1997, 1999b). It is likely that the effect of ACTH on LH surge secretion is mediated by progesterone, but the direct action of ACTH on the gonadotroph may be significant during stress.

\section{Cortisol}

In a similar manner to ACTH, cortisol has been administered to produce plasma concentrations of cortisol similar to the maximum observed during stress. For example, cortisol administered to obtain a plasma concentration of $70 \mathrm{ng} \mathrm{ml}^{-1}$ for 5 days beginning during the follicular phase suppresses follicular development and blocks the LH surge and ovulation (Macfarlane et al., 2000). This concentration is similar to peak concentrations seen in response to stress (Figs 2 and 3 ). However, even with a constant stimulus, cortisol concentrations decrease below peak values within a few hours due to habituation and cortisol negative feedback, thus prolonged constant infusion studies do not mimic physiological events (Smith and Dobson, 2002). In vitro cortisol suppresses both basal and GnRH-stimulated LH release from cattle pituitary glands ( $\mathrm{Li}$ and Wagner, 1983). Debus et al. (2002) reported that shorter periods of cortisol infusion to mimic that seen in response to endotoxin suppresses $\mathrm{LH}$ 
pulsatility acutely. However, blockade of cortisol synthesis did not prevent inhibition of LH pulsatility due to endotoxin administration, leading to the conclusion that increased cortisol itself was sufficient to account for suppression of LH pulsatility seen but the cortisol rise was not necessary for this suppression. The medial preoptic area and arcuate nucleus contain high concentrations of type II glucocorticoid receptors which are suppressed by oestradiol treatment. Like many other neurotransmitters and receptors that are involved in the control of GnRH, the glucocorticoid receptors are not co-localized with GnRH (Dufourny and Skinner, 2002). Thus, cortisol may be a significant mediator of the suppression of fertility due to stress but determining whether it is obligatory for any stimulus requires further research.

\section{Progesterone and opioids}

Plasma concentrations of progesterone, presumably secreted by the adrenal glands, increase during stress. Progesterone concentrations increase significantly from 0.11 to $0.78 \mathrm{ng} \mathrm{ml}^{-1}$ during endotoxin administration and from 0.30 to $0.38 \mathrm{ng} \mathrm{ml}^{-1}$ during transport (Phogat et al,, 1999a; Karsch et al., 2002). Administration of near-luteal phase concentrations of progesterone $\left(7 \mathrm{ng} \mathrm{ml}^{-1}\right)$ blocks both $\mathrm{LH}$ pulsatility and the $\mathrm{GnRH}$-LH surge if administered during the activation and early transmission phases, but not later. The effects of progesterone on pulsatility and during the early transmission phase are mediated by endogenous opioids (Richter et al, 2001), and arcuate nucleus opioid neurones projecting to the MPOA or ME may be the source (Conover et al., 1993). Opioids are also involved in suppression of LH pulsatility and the delay in LH surge during hypoglycaemia (Clarke et al., 1990; Dobson and Smith, 2000). However, this delay is not prevented by antagonism of nuclear progesterone receptors using RU486 (Dobson and Smith, 2000).

Thus, the inhibitory effects of stress or progesterone during pulsatile $\mathrm{LH}$ secretion and the transmission phase of the LH surge could be mediated via a common opioid interneurone, or a separate system. However, overall, these findings indicate that the low concentrations of progesterone secreted in response to stress are not involved in a genomic inhibition of the $\mathrm{LH}$ surge. This does not preclude a role for the higher concentrations of progesterone induced by prolonged doses of ACTH used in some studies. For example, Jow doses of progesterone are as effective as ACTH at experimentally producing follicular cysts (Dobson et al., 2000).

\section{Additional pathways identified for specific stressors}

\section{Endotoxin}

In vivo, low doses of endotoxin act on the pituitary gland, whereas high doses act via both the hypothalamus and pituitary gland to suppress both pulsatile and surge LH secretion (Karsch et al., 2002). There is evidence that this effect is mediated via prostaglandin synthesis (in ewes) and opioids (in heifers) (Kujjo et al., 1995; Karsch et al., 2002). Studies in rats indicate that endotoxin also acts via interleukin- $1 \alpha$ and $-\beta$ synthesized within the brain, and GABA release in the hypothalamus (Feleder et al., 1996). This is in addition to the increase in c-fos expression induced by endotoxin in many of the sites already implicated in stressinduced suppression of LH pulsatility (OVLT/medial preoptic area, PVN, arcuate nucleus/ME, central nucleus of the amygdala, locus coeruleus, nucleus of the solitary tract, area postrema and ventrolateral medulla) (Nappi et al., 1997). 


\section{Hypoglycaemia}

Opioids mediate LH suppression both in sheep during insulin-induced hypoglycaemia and in rats after administration of the glucose antagonist, 2-deoxyglucose (2DG) (Briski and Sylvester, 1999; Dobson and Smith, 2000). Nitric oxide may also be involved as 2DG elicites c-fos expression in neurones that produce nitric oxide in the MPOA, PVN and BNST in rats (Briski and Sylvester, 1999). The area postrema contains glucose-sensitive neurones that detect (relative) hypoglycaemia in rats and sheep, and ablation of this area in rats prevents the inhibition of LH pulsatility induced by insulin (Cates and O'Byrne, 2000; Ohkura et al., 2000). However, Adam and Findlay (1998) were unable to detect c-fos expression in the area postrema during insulin treatment in sheep. Conversely, another study on sheep identified c-fos in the area postrema after insulin-induced hypoglycaemia, as well as isolation and transport simulation (Vellucci and Parrott, 1994). Endotoxin administration also stimulates c-fos expression in the area postrema in rats (Nappi et al., 1997) indicating that this area may be important in the response to all stressors, not just to hypoglycaemia.

\section{Conclusions}

Limits on reproductive efficiency due to management and environmental factors imposed on domesticated ruminants have a major impact on economics of farm production. Reproductive efficiency is clearly an objective indicator of animal welfare. The relative importance of interference at each level of the reproductive system needs clarification along with all of the interrelationships involved. The role of all neurones that impinge upon the key control point, the GnRH neurone, requires identification. Elucidation of the mechanisms involved in stress-induced suppression of reproduction may allow the development of strategies to ameliorate the deleterious effects. The significance of the ever increasing range of candidate neurotransmitters requires further study in ruminants.

\section{References}

Adam CL and Findlay PA (1998) Inhibition of luteinizing hormone secretion and expression of c-fos and corticotrophin-releasing factor genes in the paraventricular nucleus during insulin-induced hypoglycaemia in sheep Journal of Neuroendocrinology $10777-783$

Anselmo Franci JA, Franci CR, Krulich L, Antunes Rodrigues J and McCann SM (1997) Locus coeruleus lesions decrease norepinephrine input into the medial preoptic area and medial basal hypothalamus and block the $\mathrm{LH}, \mathrm{FSH}$ and prolactin preovulatory surge Brain Research 767 289-296

Battaglia DF, Bowen JM, Krasa HB, Thrun LA, Viguie C and Karsch FI (1997) Endotoxin inhibits the reproductive neuroendocrine axis while stimulating adrenal steroids: a simultaneous view from hypophyseal portal and peripheral blood Endocrinology $1384273-4281$

Briski KP and Sylvester PW (1999) Site-specific induction of Fos immunoreactivity in preoptic and hypothalamic NADPH-positive neurons during glucoprivation Neuroendocrinology 69 181-190

Caraty A, Grino M, Locatelli A, Guillaume V, Boudouresque F, Conte-Devolx B and Oliver C
(1990) Insulin-induced hypoglycemia stimulates corticotropin-releasing factor and arginine vasopressin secretion into hypophysial portal blood of conscious, unrestrained rams Journal of Clinical Investigation 85 1716-1721

Caraty A, Miller DW, Delaleu B and Martin GB (1997) Stimulation of LH secretion in sheep by central administration of corticotrophin-releasing hormone Journal of Reproduction and Fertility $111249-2.57$

Cates PS and O'Byrne KT (2000) The area postrema mediates insulin hypoglycaemia-induced suppression of pulsatile $\mathrm{LH}$ secretion in the female rat Brain Research 853 151-155

Cales PS, Forsling ML and O'Byrne KT (1999) Stressinduced suppression of pulsatile luteinising hormone release in the female rat: role of vasopressin Journal of Neuroendocrinology 11 677-683

Cepoi D, Sutton S, Arias C, Sawchenko P and Vale WW (1999) Ovine genomic urocortin: cloning, pharmacologic characterization and distribution of central mRNA Molecular Brain Research 68 109-118

Chen MD, Ordog T, O'Byrne KT, Goldsmith JR, Connaughton MA and Knobil E (1996) The insulin hypoglycemia-induced inhibition of 
gonadotropin-releasing hormone pulse-generator activity in the rhesus monkey - roles of vasopressin and corticotropin-rèleasing factor Endocrinology 137 2012-2021

Clarke IJ, Horton RJE and Doughton BW (1990) Investigation of the mechanism by which insulin-induced hypoglycemia decreases luteinizing-hormone secretion in ovariectomized ewes Endocrinology 127 1470-1476

Conover CD, Kuljis RO, Rabii J and Advis JP (1993) Beta-endorphin regulation of luteinizing hormonereleasing hormone release at the median eminence in ewes: immunocytochemical and physiological evidence Neuroendocrinology 57 1182-1195

Cook CJ (2001) Measuring of extracellular cortisol and corticotropin-releasing hormone in the amygdala using immunosensor coupled microdialysis Journal of Neuroscience Methods 110 95-101

Debus N, Breen KM, Barrell GK, Billings HJ, Brown M, Young EA and Karsch FJ (2002) Does cortisol mediate endotoxin-induced inhibition of pulsatile luteinizing hormone and gonadotropin-releasing hormone secretion? Endocrinology $1433748-3758$

Dobson $\mathrm{H}$ and Smith RF (1998) Stress and subfertility Reproduction in Domestic Animals 33 107-111

Dobson $\mathrm{H}$ and Smith RF (2000) What is stress and how does it affect reproduction? Animal Reproduction Science $60743-752$

Dobson H, Tebble JE, Ozturk M and Smith RF (1999) Effect of transport on pulsatile $\mathrm{LH}$ release in ovariectomized ewes with or without prior steroid exposure at different times of year Journal of Reproduction and Fertility 117 213-222

Dobson H, Ribadu AY, Noble KM, Tebble JE and Ward WR (2000) Ultrasonography and hormone profiles of adrenocorticotrophic hormone $(\mathrm{ACTH})$-induced persistent ovarian follicles (cysts) in cattle Journal of Reproduction and Fertility $120405-410$

Dobson H, Ghuman SPS, Prabhakar S and Smith RF (2003) A conceptual model to understand the influence of stress on female reproduction Reproduction $125151-163$

Dufourny L and Skinner DC (2002) Type II glucocorticoid receptors in the ovine hypothalamus: distribution, influence of estrogen and absence of colocalization with GnRH Brain Research 946 79-86

Engler D, Pham T, Fullerton MJ, Funder JW and Clarke IJ (1988) Studies of the regulation of the hypothalamicpituitary-adrenal axis in sheep with hypothalamicpituitary disconnection. I. Effect of an audiovisual stimulus and insulin-induced hypoglycemia Neuroendocrinology $48551-560$

Evans NP, Dahl GE, Padmanabhan V, Thrun LA and Karsch FJ (1997) Estradiol requirements for induction and maintenance of the gonadotropin-releasing hormone surge: implications for neuroendocrine processing of the estradiol signal Endocrinology 138 $5408-5414$
Feleder C, Refojo D, Jarry $H$, Wuttke $W$ and Moguilevsky JA (1996) Bacterial endotoxin inhibits LHRH secretion following the increased release of hypothalamic GABA levels - different effects on amino acid neurotransmitter release Neuroimmunomodulation 3 342-351

Heisler LE, Tumber AJ, Reid RL and van Vugt DA (1994) Vasopressin mediates hypoglycemia-induced inhibition of luteinizing hormone secretion in the ovariectomized rhesus monkey Neuroendocrinology $60 \quad 297-304$

Holmberg BJ, Morrison CD and Keisler DH (2001) Endocrine responses of ovariectomized ewes to i.c.V. infusion of urocortin Joumal of Endocrinology 171 $517-524$

Jeong $\mathrm{KH}$, Jacobson $\mathrm{L}$, Widmaier EP and Majzoub JA (1999) Normal suppression of the reproductive axis following stress in corticotropin-releasing hormonedeficient mice Endocrinology 140 1702-1708

Karsch FJ, Battaglia DF, Breen KM, Debus N and Harris TG (2002) Mechanisms for ovarian cycle disruption by immune/inflammatory stress Stress 5 101-112

Kujjo LL, Bosu WT and Perez GI (1995) Opioid peptides involvement in endotoxin-induced suppression of $\mathrm{LH}$ secretion in ovariectomized Holstein heifers Reproductive Toxicology 9 169-174

Li C, Vaughan J, Sawchenko PE and Vale WW (2002) Urocortin III-immunoreactive projections in rat brain: partial overlap with sites of type 2 corticotrophin-releasing factor receptor expression Journal of Neuroscience 22 991-1001

Li PS and Wagner WC (1983) In vivo and in vitro studles on the effect of adrenocorticotropic hormone or cortisol on the pituitary-response to gonadotropinreleasing hormone Biology of Reproduction 29 $25-37$

Macfarlane MS, Breen KM, Sakurai H, Adams BM and Adams TE (2000) Effect of duration of infusion of stress-like concentrations of cortisol on follicular development and the preovulatory surge of $\mathrm{L} . \mathrm{H}$ in sheep Animal Reproduction Science 63 167-175

McNeilly AS, Picton HM, Campbell BK and Baird DT (1991) Gonadotropic control of follicle growth in the ewe Journal of Reproduction and Fertility Supplement 43 177-186

Mann GE (2001) Pregnancy rates during experimentation in dairy cows Veterinary Journal $161301-305$

Matthews SG, Heavens RP and Sirinathsinghii DJ (1991) Cellular localization of corticotropin releasing factor mRNA in the ovine brain Molecular Brain Research 11 171-176

Matthews SG, Parrott RF and Sirinathsinghji DJS (1993) Distribution and cellular localization of vasopressin mRNA in the ovine brain, pituitary and pineal glands Neuropeptides 25 11-17

Medina CL, Nagatani S, Darling TA, Bucholtz DC, Tsukamura H, Maeda KI and Foster DL (1998) Glucose availability modulates the timing of the 
Juteinizing hormone surge in the ewe Journal of Neuroendocrinology $10785-792$

Moenter SM, Caraty A and Karsch FJ (1990) The estradiol-induced surge of gonadotropin-releasing hormone in the ewe Endocrinology 127 1375-1384

Nappi RE, Bonneau MJ and Rivest S (1997) Influence of the estrous cycle on C-fos and CRH gene transcription in the brain of endotoxin-challenged female rats Neuroendocrinology 65 29-46

Naylor AM, Porter DW and Lincoln DW (1990) Central administration of corticotrophin-releasing factor in the sheep: effects on secretion of gonadotrophins, prolactin and cortisol journal of Endocrinology 124 $117-125$

Nikolarakis KE, Almeida OF, Sirinathsinghii DJ and Herz A (1988) Concomitant changes in the in vitro and in vivo release of opioid peptides and luteinizing hormone-releasing hormone from the hypothalamus following blockade of receptors for corticotropinreleasing factor Neuroendocrinology 47 545-550

Ohkura S, Tanaka T, Nagatani S, Bucholtz DC, Tsukamura H, Maeda KI and Foster DL (2000) Central, but not peripheral, glucose-sensing mechanisms mediate glucoprivic suppression of pulsatile luteinizing hormone secretion in the sheep Endocrinology $1414472-4480$

Palkovits M, Brownstein MJ and Vale W (1983) Corticotropin releasing factor (CRF) immunoreactivity in hypothalamic and extrahypothalamic nuclei of sheep brain Neuroendocrinology 37 302-305

Paull WK, Scholer J, Arimura A, Meyers CA, Chang JK, Chang D and Shimizu M (1982) Immunocytochemical localization of CRF in the ovine hypothalamus Peptides 3 183-191

Phogat JB, Smith RF and Dobson H (1997) Effect of adrenocorticotrophic hormone on gonadotrophin releasing hormone-induced luteinizing hormone secretion in vitro. Animal Reproduction Science $\mathbf{4 8}$ 53-65

Phogat JB, Smith RF and Dobson H (1999a) Effect of transport on pituitary responsiveness to exogenous pulsatile $\mathrm{GnRH}$ and oestradiol-induced $\mathrm{LH}$ release in intact ewes Journal of Reproduction and Fertility 116 9-18

Phogat JB, Smith RF and Dobson H (1999b) Effect of adrenocorticotrophic hormone (ACTH(1-24)) on ovine pituitary gland responsiveness to exogenous pulsatile $\mathrm{GnRH}$ and oestradiol-induced $\mathrm{LH}$ release in vivo. Animal Reproduction Science 55 193-203

Polkowska J and Przekop F (1997) The effect of corticotropin-releasing factor (CRF) on the gonadotropin hormone releasing hormone (GnRH) hypothalamic neuronal system during preovulatory period in the ewe Acta Neurobiologiae Experimentalis 57 91-99

Rasmussen DD and Malven PV (1983) Effects of confinement stress on episodic secretion of $\mathrm{LH}$ in ovariéctomized sheep Neuroendocrinology 36 392-396
Richter TA, Spackman DS, Robinson JE, Dye S, Harris TG, Skinner DC and Evans NP (2001) Role of endogenous opioid peptides in mediating progesteroneinduced disruption of the activation and transmission stages of the GnRH surge induction process Endocrinology $1425212-5219$

Rivier C and Rivest S (1991) Effect of stress on the activity of the hypothalamic-pituitary-gonadal axis: peripheral and central mechanisms Biology of Reproduction 45 523-532

Roozendaal MM, Swarts JJM, Wolbers WB, Threels A, Wiegant VM and Mattheij JAM (1996) Effect of CRH on the preovulatory $\mathrm{LH}$ and FSH surge in the cyclic rat, a role for arginine vasopressin? Journal of Neuroendocrinology $\mathbf{8} 765-770$

Schulz C and Lehnert $\mathbf{H}$ (1996) Activation of noradrenergic neurons in the locus coeruleus by corticotropinreleasing factor. A microdialysis study Neuroendocrinology $63 \quad 454-458$

Smart D (1994) Adrenocorticotrophin (ACTH) 1-39 and corticotrophin releasing hormone $(\mathrm{CRH})$ induced changes in luteinizing hormone secretion from perifused ovine pituitaries Animal Reproduction Science $3725-34$

Smith RF and Dobson H (2002) Hormonal interactions within the hypothalamus and pituitary with respect to stress and reproduction in sheep Domestic Animal Endocrinology 23 75-85

Tellam DJ, Mohammad YN and Lovejoy DA (2000) Molecular integration of hypothalamo-pituitaryadrenal axis-related neurohormones on the $\mathrm{GnRH}$ neuron Biochemistry and Cell Biology-Biochimie Et Biologie Cellulaire 78 205-216

Tilbrook AJ, Turner AI and Clarke IJ (2000) Effects of stress on reproduction in non-rodent mammals: the role of glucocorticoids and sex differences Reviews of Reproduction 5 105-113

Van Cleeff J, Karsch FJ and Padmanabhan V (1998) Characterization of endocrine events during the periestrous period in sheep after estrous synchronization with controlled internal drug release (CIDR) device Domestic Animal Endocrinology 15 23-34

Van Vugt DA, Piercy J, Farley AE, Reid RL and Rivest S (1997) Luteinizing hormone secretion and corticotropin-releasing factor gene expression in the paraventricular nucleus of rhesus monkeys following cortisol synthesis inhibition Endocrinology 138 2249-2258

Vellucci SV and Parrott RF (1994) Expression of c-fos in the ovine brain following different types of stress, or central administration of corticotropin-releasing hormone Experimental Physiology 79 241-248

Xiao E, Xia-Zhang $\mathbf{L}$ and Ferin $\mathbf{M}$ (2002) Inadequate luteal function is the initial clinical cyclic defect in a 12-day stress model that includes a psychogenic component in the rhesus monkey Journal of Clinical Endocrinology and Metabolism $872232-$ 2237 